\title{
Comparison of Linear and Nonlinear Optimization Methods of Heating Plant Operation
}

Peter Muškát, František Urban, Jozef Bereznai, Zdenko Závodný

Faculty of Mechanical Engineering STU in Bratislava, Nám. Slobody 17, 81231 Bratislava, peter.muskat@stuba.sk

The article presents comparison of optimization methods applied to operation of the heating plant. Optimizing problems are possible to solve with using of methods of the linear programming (LP) or nonlinear programming (NLP). In the paper method of differential addition (LP, NLP), method of characteristics (LP), simplex method (LP), method of Lagrange multipliers (LP, NLP) and method of hyperplane in n - dimensional space (LP, NLP) are presented from point of view of requirements for designing and modifications of the program, requirements on system memory and computation time, comparison of the optimizing methods for loading of the thermal power machines and devices.

Keywords: heat source, optimizing criterion, optimizing methods, heat source operation, fuel costs

\section{References}

[1] URBAN, F., FODOR, P. (2015). Optimalizácia zdrojov tepla v tepelných sústavách. Bratislava VERT. 127 s. ISBN 978-80-970957-8-9.

[2] URBAN, F., MUŠKÁT, P., ZÁVODNÝ, Z. (2015). Zostavenie energetických a ekonomických charakteristík energetických strojov a zariadení. In: Vykurovanie 2015: SSTP, s. 113-117. ISBN 978-80-89216-69-7.

[3] HOLUBČÍK, M., JANDAČKA, J., PAPUČÍK, Š., PILÁT, P. (2015). Performance and Emission Parameters Change of Small Heat Source Depending on the Moisture. In: Manufacturing Technology, Vol. 15, No. 5, p. 826829, ISSN 1213-2489.

[4] BUKOVIANSKY, M., TAKÁCS, J. (2012). Centralizované zásobovanie teplom a vel'koobjemové systémy. In: TZB Haustechnik, ISSN 1210-356X, Roč.20, č.3, s. 20-23

[5] XIA, J., ZHU, K., JIANG, Y. (2016). Method for integrating low-grade industrial waste heat into district heating network. In: Building Simulation, 9 (2), SCOPUS, pp. 153-163.

[6] FANG, T., LAHDELMA, R. (2015). Genetic optimization of multi-plant heat production in district heating networks. In: Applied Energy, 159, SCOPUS, pp. 610-619.

[7] BASAlAEV, A.A., BARBASOVA, T.A., SHNAYDER, D.A. (2015). Simulation study on supply temperature optimization of university campus heating system. In: Procedia Engineering, 129, SCOPUS, pp. 587-594.

[8] NAVRATIL, P., PEKAR, L. (2012). Possible approach to creation and utilization of linear mathematical model of heat source for optimization of combined production of heat and electric energy. In: International Journal of Mathematical Models and Methods in Applied Sciences, 6 (8), SCOPUS, pp. 943-954.

[9] NAVRATIL, P., KLAPKA, J., BALATE, J., KONECNY, P. (2012). Optimization of load of heat source described by nonlinear mathematical model. In: Mendel, SCOPUS, pp. 356-362.

[10] MURAI, MASAHIKO, SAKAMOTO, YOSHIYUKI, SHINOZAKI, TSUTOMU (1999). Optimizing control for district heating and cooling plant. In: IEEE Conference on Control Applications - Proceedings, 1, SCOPUS, pp. 600-604. 